\title{
Pertumbuhan dan Produktivitas Daun Lamun Thalassia hemprichii (Ehrenb) Ascherson di Perairan Tanjung Benoa, Bali
}

\author{
Budi Santoso a*, I Gusti Bagus Sila Dharma a, Elok Faiqoh a \\ a Program Studi Ilmu Kelautan, Fakultas Kelautan dan Perikanan, Universitas Udayana, Kampus UNUD Bukit Jimbaran, Bali 80361, Indonesia
}

* correspomding outor. Tel.: +6285738281843

e-mail: budi_santoso1366@yahoo.com

Diterima (received) 20 Juni 2017; disetujui (accepted) 7 November 2017; tersedia secara online (available online) 8 November 2017

\begin{abstract}
Thalassia hemprichii is one of the seagrass as favorite food of two protected herbivores such as Green Turtle and Dugong. The existence of Thalassia hemprichii and knowing the growth rate becomes very important for sustainability of two herbivores. The study was conducted in Tanjung Benoa waters that covering three parts of the coast such as Samuh, Conrad and Tanjung beach in February until March 2017. Thalassia hemprichii leaves growth is observed consist of long and heavy growth (dry weight) and measured leaf age that has been observed such as young, half old and old leaves. The method that used to measure the growth of Thalassia hemprichii is pruning method and determination the research location using purposive sampling method. The aim of this research is explained the growth rate, biomass, and productivity of young leaves, old leaves of Thalassia hemprichii in Tanjung Benoa Bali. Measurement results of Thalassia hemprichii growth between age group of leaves has different young leaves faster growth if compared with the half old leaves and old leaves with average growth is $3.41 \mathrm{~mm} /$ day indicates that the efficiency of this seagrass growth will decrease as the leaves age. The highest biomass values were found in older leaves if compared with young leaves and half-old leaves with average $0.205 \mathrm{gbk} / \mathrm{m}^{2}$ expected because the thick and wide leaf size will produced larger leaf biomass. The highest productivity value is found in oldest leaves in each station with average $0.028 \mathrm{gbk} / \mathrm{m}^{2} /$ day expected morphology and different nutrient content in each leaf tissue.
\end{abstract}

Keywords: biomass, growth, productivity, Tanjung Benoa.

\begin{abstract}
Abstrak
Thalassia hemprichii merupakan salah satu jenis lamun yang menjadi makanan favorit dua herbivora yang dilindungi yaitu Penyu Hijau dan Dugong. Keberadaan Thalassia hemprichii dan mengetahui kecepatan pertumbuhannya menjadi sangat penting untuk keberlangsungan dua herbivora tersebut. Penelitian dilaksanakan di perairan Tanjung Benoa meliputi tiga bagian pantai diantaranya pantai Samuh, pantai Conrad serta pantai Tanjung pada bulan Pebruari hingga Maret 2017. Pertumbuhan daun lamun Thalassia hemprichii yang diamati terdiri dari pertumbuhan panjang dan berat (berat kering) serta diukur umur daun yang telah diamati seperti daun muda, daun setengh tua dan daun. Metode yang digunakan untuk mengukur pertumbuhan daun lamun Thalassia hemprichii adalah metode pemangkasan serta dalam penentuan lokasi penelitian menggunakan metode Purposive sampling. Tujuan penelitian ini adalah mengetahui laju pertumbuhan, biomassa, dan produktivitas daun muda, daun setengah tua, daun tua dari jenis lamun Thalassia hemprichii di kawasan Tanjung Benoa Bali. Hasil Pengukuran pertumbuhan daun lamun Thalassia hemprichii antara kelompok umur daun memiliki nilai berbeda daun muda lebih cepat pertumbuhannya dibandingkan dengan daun setengah tua dan daun tua dengan rata-rata pertumbuhan sebesar $3.41 \mathrm{~mm} / \mathrm{hari}$ ini menunjukan bahwa efisiensi pertumbuhan lamun ini akan semakin menurun dengan bertambahnya umur daun. Nilai biomassa tertinggi terdapat pada daun tua dibandingkan dengan daun muda dan daun setengah tua dengan rata-rata sebesar $0.205 \mathrm{gbk} / \mathrm{m}^{2}$ diduga karena ukuran daun yang tebal dan lebar yang mengakibatkan biomassa daun tua tersebut lebih besar. Nilai produktivitas tertinggi terdapat pada daun tertua disetiap stasiunnya dengan rata-rata sebesar $0.028 \mathrm{gbk} / \mathrm{m}^{2} /$ hari diduga morfologi serta kandungan unsur hara yang berbeda disetiap jaringan daun.
\end{abstract}

Kata Kunci: biomassa, pertumbuhan, produktivitas, Tanjung Benoa. 


\section{Pendahuluan}

Thalassia hemprichii merupkan salah satu jenis lamun yang tumbuh di perairan tropik dan penyebarannya cukup luas yang memiliki fungsi sebagai tempat berlindung sekaligus memijah (spawning ground), tempat berkembangbiak, daerah pengasuhan (nursery ground), dan tempat mencari makan (feeding ground) khususnya bagi biota perairan laut sekaligus makanan kesukaan hewan herbivora (Alie, 2010).

Diantara ekosistem yang ada di laut, lamun merupakan ekosistem yang memiliki produktivitas tertinggi (Febriyantoro dkk., 2013) sehingga secara tidak langsung, lamun berperan dalam peyerapan karbon di alam. Tumbuhan lamun dapat mengikat sekitar 1650 juta ton karbondioksida pertahun atau kurang lebih separuh dari emisi kegiatan transportasi global (Kawaroe, 2009).

Produksi karbon dalam padang lamun diambil dengan pendekatan pengambilan informasi pertambahan jumlah karbon dan timbunan karbon dalam bentuk biomassa. Menurut Rahmawati (2011) produksi karbon yang diserap oleh lamun dialirkan ke hewan herbivora, ditimbun sebagai serasah dan disimpan didalam jaringan lamun itu sendiri. Selain itu perbedaan jenis lamun dapat memberikan kontribusi yang bervariasi terhadap biomassa dan produktivitas.

Biomassa lamun yang dimaksud dalam penelitian ini adalah berat dari material yang hidup pada suatu satuan luas tertentu yang berada di atas substrat yang sering dinyatakan dalam satuan gram berat kering per $\mathrm{m}^{2}\left(\mathrm{gbk} / \mathrm{m}^{2}\right)$. Sedangkan produktivitas lamun diartikan sebagai pertambahan biomassa lamun selang waktu tertentu yang sering dinyatakan dengan satuan berat kering per $\mathrm{m}^{2}$ per hari $\left(\mathrm{gbk} / \mathrm{m}^{2} /\right.$ hari) (Asriana dan Yuliana, 2012).

Di daerah selatan Bali, salah satu lokasi yang memiliki komunitas lamun melimpah adalah daerah Tanjung Benoa. Tanjung Benoa secara administratif masuk ke wilayah kelurahan Benoa, Kecamatan Kuta Selatan Kabupaten Badung. Lamun didaerah ini menyebar di sepanjang pantai bagian Timur kawasan ini dikenal sebagai daerah wisata yang memiliki berbagai aktifitas wisata mulai dari aktifitas pinggir pantai seperti berenang, mandi maupun aktifitas water sport, selain itu masyarakat sekitar yang berprofesi sebagai nelayan menyandarkan perahu-perahunya dikawasan tersebut. Meningkatnya aktivitas manusia di sekitar kawasan Tanjung Benoa tanpa memperhatikan daya dukung lingkungan, dapat mempercepat terjadinya kerusakan komunitas lamun itu sendiri, jika padang lamun rusak maka potensi sumberdaya alam laut dan penyerapan karbon juga akan berkurang (Faiqoh, 2015).

Penelitian mengenai produktivitas dan biomassa lamun telah banyak dilakukan diantaranya Russell et al. (2013), Hill et al. (2014), Kaswadji et al. (2012), dan Graha et al. (2004), namun di kawasan Tanjung Benoa Bali belum pernah dilakukan. Mengingat pentingnya lamun dalam mendukung penyerapan karbon di alam dan di Pulau Bali khususnya, maka diperlukan penelitian yang menghasilkan data kuantitatif tentang seberapa penyerapan karbon dengan pendekatan biomassa dan produktivitas maka penelitian ini sangat penting dilakukan sebagai data awal dan landasan pengelolaan lingkungan dengan tepat, sehingga dapat menjamin keberadaan ekosistem padang lamun secara berkelanjutan di suatu daerah.

Tujuan dari penelitian ini adalah mengetahui laju pertumbuhan, biomassa, dan produktivitas daun muda, daun setengah tua, daun tua dari jenis lamun Thalassia hemprichii di kawasan Tanjung Benoa, Bali.

\section{Metode Penelitian}

\subsection{Lokasi Penelitian}

Penelitian dilaksanakan di Kawasan Bali Selatan yaitu di perairan Tanjung Benoa (Gambar 1) pada bulan Pebruari sampai dengan Maret 2017 Perincian waktu persiapan dan hingga pelaksanaan pengambilan sampel lamun berlangsung selama 1 bulan. Selanjutnya untuk melakukan pengolahan dan analisis data, dilakukan di Laboratorium Ilmu Kelautan Fakultas Kelautan Dan Perikanan Universitas Udayana.

\subsection{Alat dan bahan}

Alat yang digunakan dalam penelitian ini berupa transek kuadrad berukuran $1 \times 1 \mathrm{~m}$, alat tulis, jangka sorong, kamera, Refrakto, $\mathrm{pH}$ meter, DO meter, Gps, Gunting, Gabus, plastik, roll meter, coolbox, thermometer, kertas label, Alat dasar selam, bahan yang digunakan dalam penelitian ini adalah lamun jenis Thalassia hemprichii. 


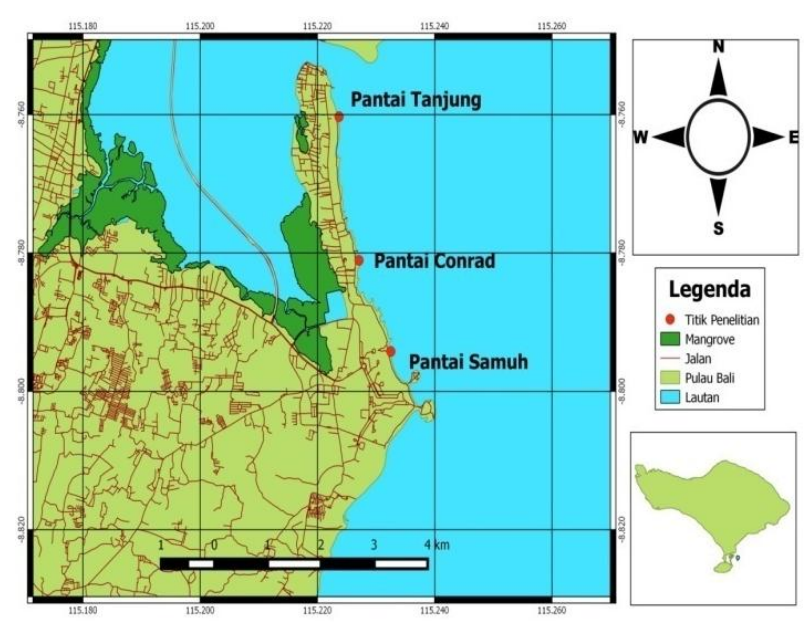

Gambar 1. Lokasi penelitian

\subsection{Penentuan Titik Pengamatan}

Menentukan titik pengamatan dengan berdasar pada data hasil observasi awal yang telah dilakukan. Penentuan lokasi penelitian menggunakan metode Purposive sampling yang dilakukan dengan memilih keterwakilan dari lokasi penelitian secara keseluruhan berdasarkan pada kondisi lingkungan dasar perairan yang ditumbuhi Thalassia hemprichii Gambar 2.

Pengambilan data menggunakan transek kuadrat. transek yang digunakan dalam penelitian ini berukuran 1x1 meter tanpa adanya subpiksel pada transek tersebut. Pemilih stasiun pengamatan dilakukan dengan cara menarik garis lurus sepanjang 50 meter kearah laut. Adapun jarak antar substasiun pengamatan adalah 25 meter.

\subsection{Pengambilan Sampel}

\subsubsection{Pertumbuhan Daun Lamun}

Pertumbuhan pertunas daun lamun Thalassia hemprichii yang diamati terdiri dari pertumbuhan panjang dan berat (berat kering) serta diukur umur daun yang telah diamati seperti daun muda (berwarna hijau muda dan lebih tipis serta sempit terletak diantara daun tertua dan daun setengah tua terdapat dilapisan paling dalam dari daun lamun) daun tua (berwarna hijau kekuningan sampai hijau kecoklatan tebal serta lebar terletak pada lapisan paling luar) daun setengah tua (berwarna hijau tua sedikit tebal dan lebar). Metode yang digunakan untuk mengukur pertumbuhan daun lamun Thalassia hemprichii adalah metode pemangkasan. Metode ini diperkenalkan oleh (Zieman, 1974). Metode pemangkasan merupakan salah satu metode penelitian pertumbuhan lamun yang telah diterima oleh para peneliti sebagai metode terbaik untuk pertumbuhan lamun (Azkab, 2006). Metode pemangkasan ini telah banyak dimodifikasi oleh para peneliti yang sesuai dengan situasi maupun kondisi di lapangan. Pada penelitian ini jarak referensi pertumbuhan di tentukan dari selubung daun. Pada hari pertama dilakukan pemilihan tunas atau tegakan pada masing-masing substasiun dalam pengamatan. Setiap substasiun dipilih tunasnya kemudian dilakukan pemangkasan pada tunas tersebut. Tunas yang sudah dipilih ditandai dengan tali dan diikat,

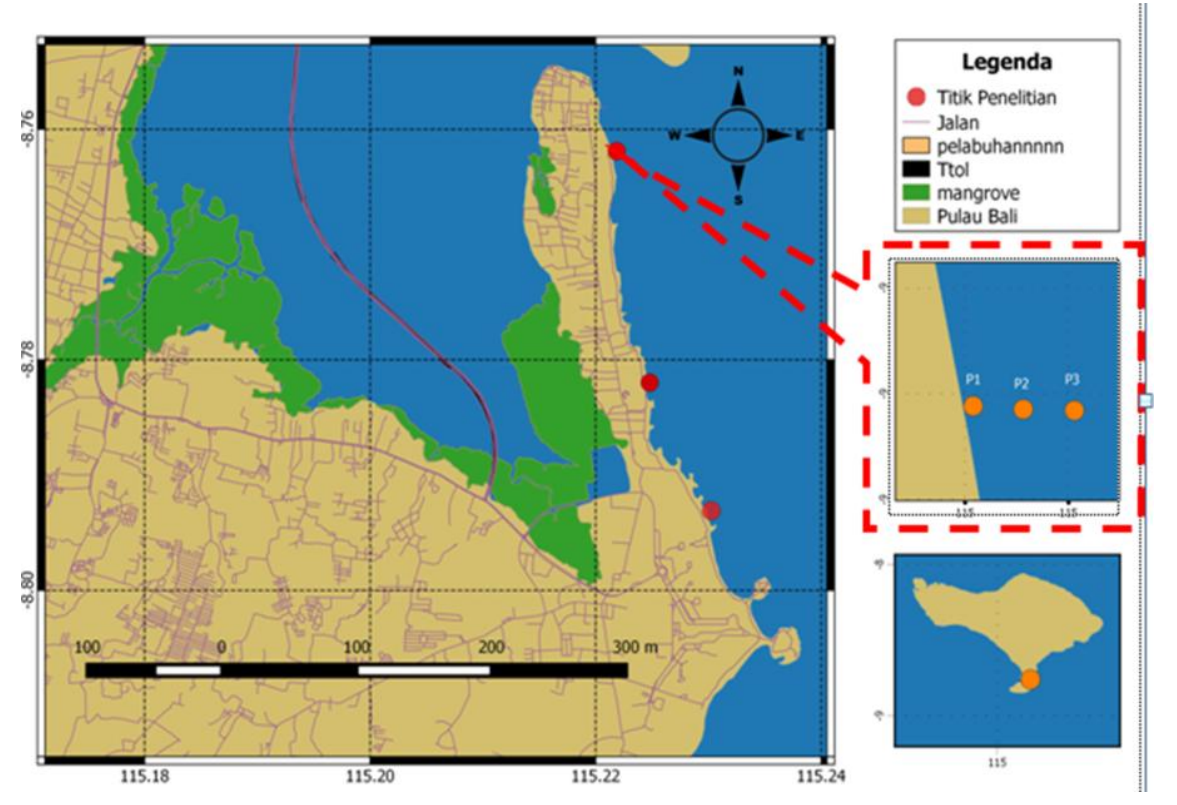

Gambar 2. Penentuan lokasi pengamatan 
untuk mempermudahnya pengamatan kemudian diberikan gabus untuk menandai tempat sampel pengamatan. Daun akan dipangkas setiap minggunya dan daun akan dibedakan antara daun muda, daun setengah tua, daun tua. Selanjutnya sampel akan dibawa ke Laboratorium Fakultas Kelautan dan Perikanan Universitas Udayana untuk dilakukan analisis lebih lanjut.

\subsubsection{Biomassa dan Produktivitas}

Pengukuran biomassa dan produktivitas daun lamun dilakukan dengan mengambil sampel lamun dari masing-masing substasiun pengamatan. Sampel lamun yang diambil adalah bagian daun. Selanjutnya sampel yang telah diambil di bersihkan untuk menghilangkan epifit (kotoran yang menempel di daun) di atas daun dengan cara dikerik secara perlahan dan hati-hati menggunakan silet dan diberikan alkohol pada daun agar benar-benar bersih tidak terdapat kotoran. Kemudian sampel akan dikeringkan dengan menggunakan tisu lalu dibungkus kedalam alumunium foil untuk di oven. Setelah sampel kering maka ditimbang, setelah ditimbang akan diperoleh nilai gram berat kering dari daun yang telah diamati dengan satuan $\left(\mathrm{gbk} / \mathrm{m}^{2}\right)$, untuk menentukan nilai produktivitas dibagi dengan interval waktu yang telah ditentukan dalam penelitian ini dan nantinya akan didapat nilai produktivitas dengan satuan ( $\mathrm{gbk} / \mathrm{m}^{2} /$ hari). Analisis ini dilakukan di Laboratorium Fakultas Kelautan dan Perikanan Universitas Udayana.

\subsection{Analisis Data}

\subsubsection{Pertumbuhan daun Thalassia hemprichii}

Pertumbuhan Thalassia hemprichii diukur dengan menggunakan persamaan (Dennison 1990 in Hamid, 1996):

$K t=\frac{B t}{t}$

Dimana :

$\mathrm{K} \mathrm{t}=$ Pertumbuhan daun lamun $\mathrm{t}(\mathrm{mm})$

$\mathrm{t}=$ Waktu interval pengamatan (hari)

$\mathrm{Bt}=$ Pertumbuhan pertunas $(\mathrm{mm} /$ hari $)$

2.6.2. Biomassa daun Thalassia hemprichi

$B=\frac{W}{A}$

Dimana :

$\mathrm{B}=$ Biomassa $\left(\mathrm{gbk} / \mathrm{m}^{2}\right)$

$\mathrm{W}=$ Berat Kering Daun Lamun (gbk)

$\mathrm{A}=$ Luas area $\left(\mathrm{m}^{2}\right)$

\subsubsection{Produktivias Lamun Thalassia hemprichii}

Produktivitas daun T.hemprichii dapat dihitung persatuan luas dari rerataan pertumbuhan pertunas dan kepadatannya (Dennison, 1990 in Hamid,1996).

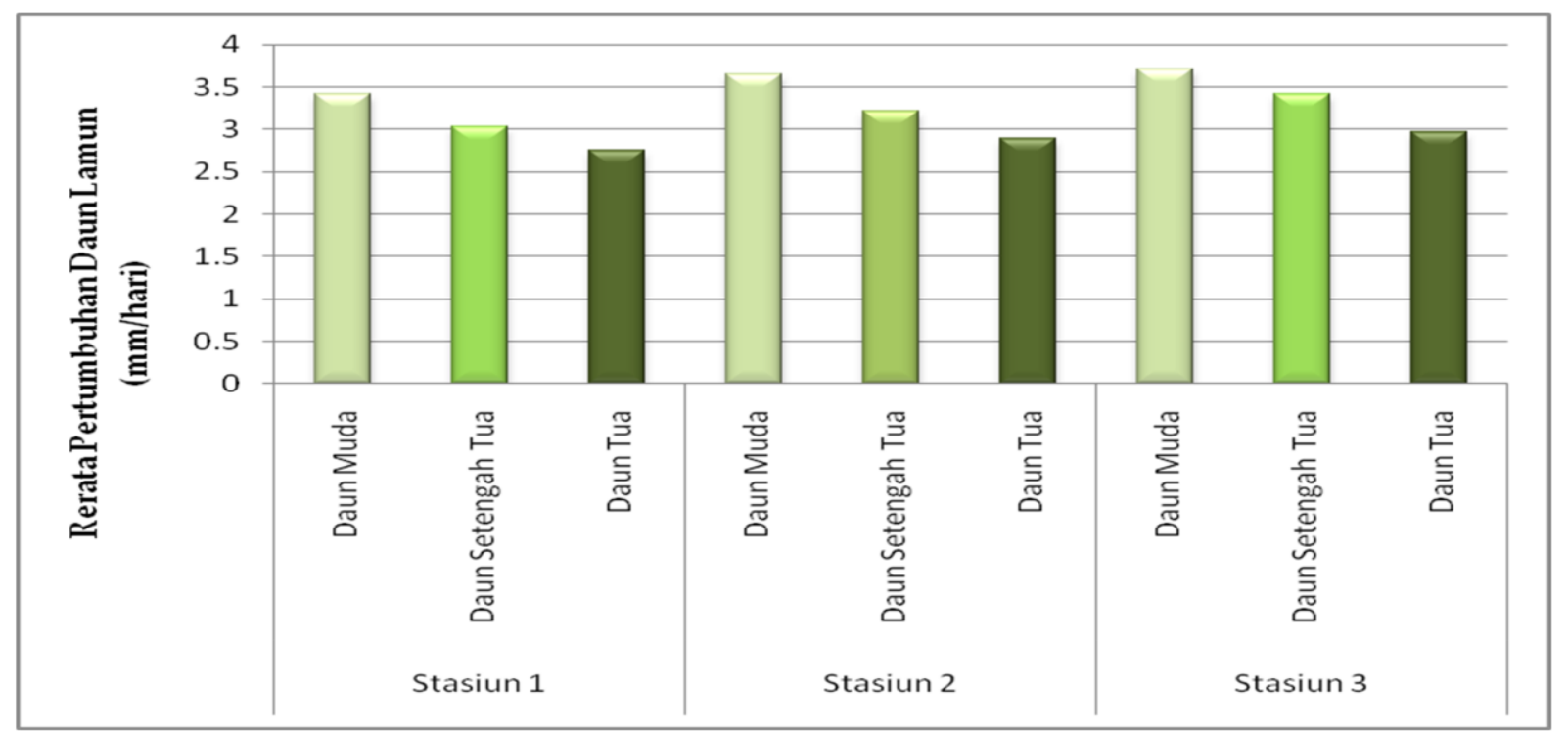

Gambar 3. Rerata pertumbuhan daun lamun Thalassia hemprichii 


$$
P t=\frac{K t}{A}
$$

Dimana :

$\mathrm{Pt}=$ Produksi daun persatuan luas $\left(\mathrm{gbk} / \mathrm{m}^{2} / \mathrm{hari}\right)$

$\mathrm{Kt}=$ Pertumbuhan Daun $(\mathrm{gbk} / \mathrm{mm} /$ hari $)$

$A=$ Luas area $\left(\mathrm{m}^{2}\right)$

\section{Hasil dan Pembahasan}

\subsection{Pertumbuhan Pertunas Daun Lamun Thalassia hemprichii}

Pengukuran pertumbuhan daun lamun Thalassia hemprichii yang dilakukan dalam penelitian ini berupa pertumbuhan panjang daun, pertumbuhan panjang yang dimaksud adalah selisih panjang daun yang tumbuh dengan interval waktu yang telah ditentukan (Tujuh hari). Hasil pengamatan rata-rata pertumbuhan panjang pertunas daun lamun Thalassia hemprichii disajikan pada Gambar 3.

Pada Gambar 3 terlihat rerata pertumbuhan panjang pertunas daun lamun Thalassia hemprichii tidak sama pada setiap stasiun, antar kelompok umur dan tempat tumbuhnya. Rerata pertumbuhan panjang pertunas terlihat trendnya menurun untuk stasiun pertama daun muda sebesar $3.41 \mathrm{~mm} /$ hari, daun setengah tua sebesar $3.02 \mathrm{~mm} /$ hari dan daun tua $2.27 \mathrm{~mm} /$ hari, pada stasiun kedua didapatkan rerata pertumbuhan daun muda sebesar $3.65 \mathrm{~mm} /$ hari, daun setengah tua sebesar $3.21 \mathrm{~mm} /$ hari dan tua didapatkan sebesar $2.89 \mathrm{~mm} /$ hari, dan pada stasiun ketiga didapat rerata nilai pertumbuhan daun muda sebesar $3.70 \mathrm{~mm} /$ hari, daun Setengah tua sebesar $3.42 \mathrm{~mm} /$ hari serta daun tua sebesar $2.97 \mathrm{~mm} /$ hari.

Hasil pengukuran terlihat bahwa daun muda dan daun setengah tua masih aktif dalam melakukan pertumbuhan panjang, sedangkan daun tua sudah mulai tidak aktif dalam melakukan pertumbuhan, hal ini diduga karena kandungan didalam setiap daun yang mempengaruhi aktivitas fotosintesis (Rahman et al., 2016). Menurut Kiswara (2010) daun lamun sebelum mati terlebih dahulu akan memindahan unsur haranya ke daun yang masih aktif tumbuh dan aktivitas berfotosintesis daun Thalassia hemprichii akan semakin menurun jika daun tersebut bertambah tua.
Daun muda lebih cepat tumbuh diduga karena struktur jaringan belum sepenuhnya mampu dalam beradaptasi dengan lingkungan laut, hal ini ditandai dengan masih tipisnya daun lamun yang mengindikasikan bahwa daun belum mampu toleran terhadap fluktuasi salinitas yang mungkin terjadi, lain halnya dengan daun setengah tua (daun sedang) yang telah mencapai tahap stabil struktur yang sempurna, tebal dan kaku mampu bertoleransi terhadap salinitas yang tinggi dan menjalankan fungsinya menyerap nutrient dari kolom air dan berbeda pula dengan daun tua karena sudah mendekati fase peluruhan laju pertumbuhannya pun mulai melambat dibandingkan dengan daun muda dan daun setengah tua (Riniatsih dan Endarwati, 2013).

Menurut Takaendengan (2010) adanya perbedaan pertumbuhan panjang menunjukan bahwa pertumbuhan daun lamun dipengaruhi oleh beberapa faktor internal seperti fisiologi, metabolisme dan faktor eksternal seperti unsur hara sebagai nutrient, tingkat kesuburan substrat dan parameter lingkungan yang ada. Hasil pengukuran parameter lingkungan terlihat bahwa di semua stasiun penelitian di perairan tanjung benoa adalah dominan pasir. Hal ini sejalan dengan yang diungkapkan Christon dkk. (2012) bahwa lamun yang tumbuh pada dasar perairan pasir dan puing karang dengan air jernih memiliki ukuran daun yang lebih kecil, rimpang tegak lebih pendek dibandingkan dengan lamun yang berada pada dasar perairan lumpur dan air keruh.

\subsection{Biomassa Daun Lamun Thalassia hemprichii}

Blue carbon atau karbon biru adalah tumbuhan yang memanfaatkan karbon melalui proses fotosintesis untuk pertumbuhan dan menyimpannya dalam biomassa. Lamun merupakan salah satu potensi blue carbon di perairan pesisir selain mangrove, rumput laut dan fitopankton. Duarte et al (2010) mengatakan bahwa potensi lamun selain menyimpan karbon di biomassa juga berpotensi menyimpan biomassa yang luruh (serasah) dan terdekomposisi di dalam sedimen.

Biomassa lamun yang dimaksudkan dalam penelitian ini adalah berat dari material yang hidup pada satuan luasan tertentu yang berada diatas substrat, pengukuran biomassa lamun ini diperoleh dari berat kering daun setelah dikeringkan dalam oven pada suhu $60^{\circ} \mathrm{C}$ selama 


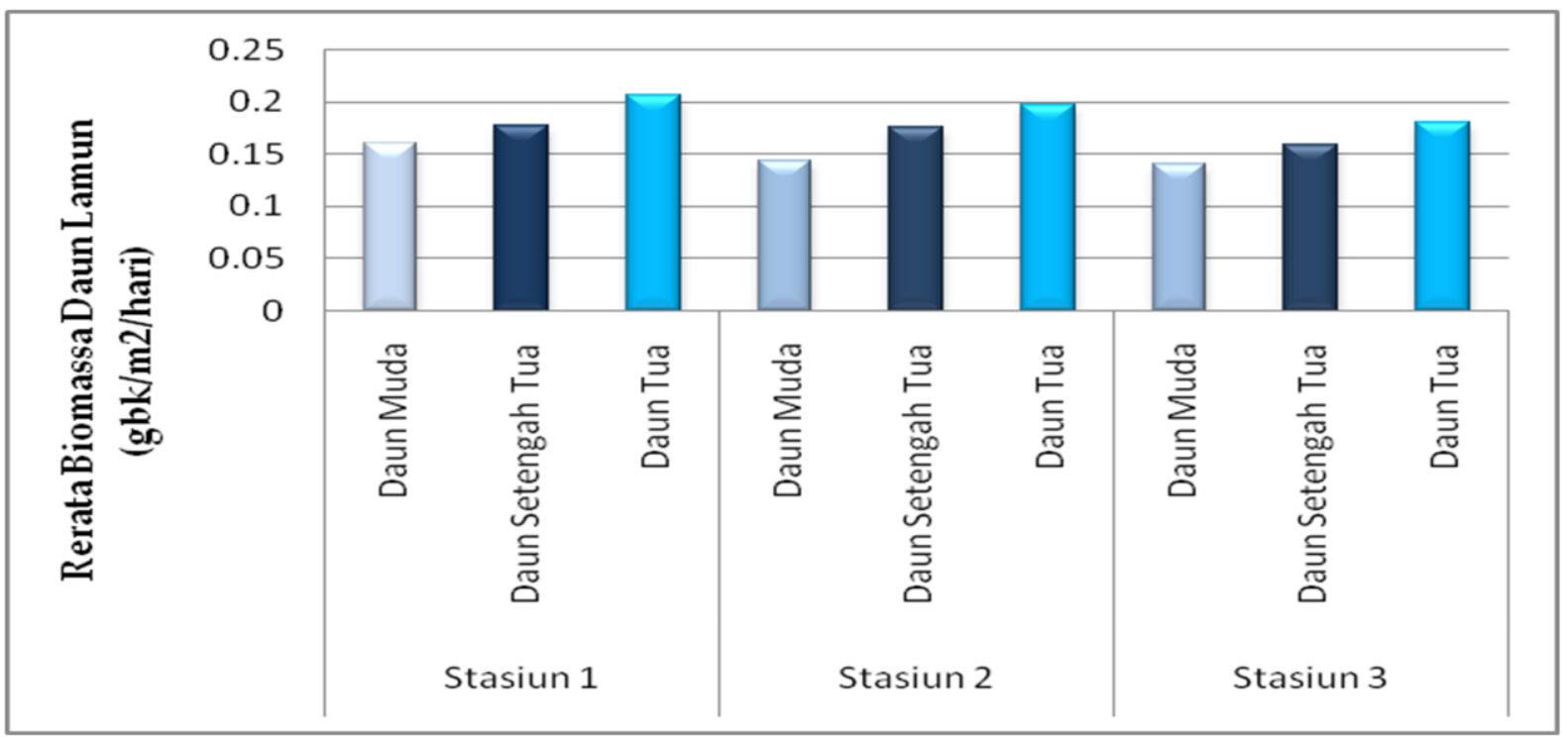

Gambar 4. Rerata biomassa daun lamun Thalassia hemprichii

24 jam. Hasil Biomassa daun lamun disajikan pada Gambar 4.

Hasil penimbangan rerata biomasa daun lamun Thalassia hemprichii jika dilihat dari gambar 4 terlihat bahwa trendnya meningkat. Nilai yang didapat di setiap stasiunnya dari daun muda, daun setengah tua dan daun tua berturut-turun didapatkan sebesar $0.159 \mathrm{gbk} / \mathrm{m}^{2}, 0.177 \mathrm{gbk} / \mathrm{m}^{2}$, $0.205 \mathrm{gbk} / \mathrm{m}^{2}$ pada stasiun kedua didapatkan nilai biomassa daun muda sebesar $0.143 \mathrm{gbk} / \mathrm{m}^{2}$, daun Setengah tua sebesar $0.176 \mathrm{gbk} / \mathrm{m}^{2}$, serta daun tua sebesar $0.197 \mathrm{gbk} / \mathrm{m}^{2}$ dan stasiun ketiga didapatkan nilai biomassa pada daun muda sebesar $0.139 \mathrm{gbk} / \mathrm{m}^{2}$, daun setengah tua sebesar $0.158 \mathrm{gbk} / \mathrm{m}^{2}$ dan daun tua sebesar $0.180 \mathrm{gbk} / \mathrm{m}^{2}$.

Dilihat dari hasil penelitian, nilai tertinggi terdapat pada stasiun pertama diduga karena perbedaan kondisi lingkungan yang terjadi serta morfologi daun seperti panjang dan lebar dibandingkan dengan stasiun kedua dan ketiga. Menurut Badria (2007) mengatakan bahwa semakin cepat pertumbuhan dan produksi daun maka biomassa yang dihasilkan pun bertambah besar pula. Namun pada penelitian kali ini teori yang disampaikan Azkab (2006) tidak sama dengan hasil yang didapat, daun tua memiliki nilai biomassa tertinggi jika dikaitkan dengan pertumbuhan seharusnya daun muda lah memiliki nilai terbesar ini diduga karena morfologi daun yang berbeda (daun tua memiliki daun lebar dan tebal) yang memungkinkan memiliki nilai tertinggi. Menurut Simon dan Rifai (2013), besarnya biomassa lamun bukan dilihat dari ukuran tumbuhnya melainkan juga dari kerapatan, semakin tinggi kerapatan lamun maka nilai biomassa juga akan tinggi.

Melihat dari hasil perbedaan tumbuh pertunas antar kelompok umur ditiap stasiunnya diduga berkaitan dengan konsentrasi klorofil dan unsur hara dalam jaringan daun, secara visual daun muda lebih sempit dan tipis dibandingkan dengan daun setengah tua dan daun tua yang mengakibatkan hasil dari biomassa daun tersebut lebih kecil. Kestabilan ekosistem lamun terkait erat dengan morfologi dari lamun itu sendiri, pada umumnya rasio biomassa antara bagian bawah (below ground) dan bagian atas (upper ground) dari lamun lebih besar di bagian bawah sehingga mudah mengikat sedimen (Tasabaramo et al., 2015).

\subsection{Produktivitas Daun Lamun Thalassia hemprichii}

Produktivitas lamun dalam penelitian ini diartikan sebagai pertambahan biomassa lamun selang waktu tertentu yang sering dinyatakan dengan satuan berat kering per $\mathrm{m}^{2}$ per hari $\left(\mathrm{gbk} / \mathrm{m}^{2} / \mathrm{hari}\right)$. Hasil produktivitas (Jumlah karbon yang dihasilkan perhari) disajikan pada Gambar 5.

Dilihat dari hasil pada Gambar 5 rerata Produktivitas daun lamun Thalassia hemprichii terlihat trennya hampir sama dengan pertumbuhan dan biomassa yaitu naik, produktivitas tertinggi terdapat pada daun tua disetiap stasiunnya. pada stasiun pertama didapatkan nilai produktivitas daun muda sebesar 


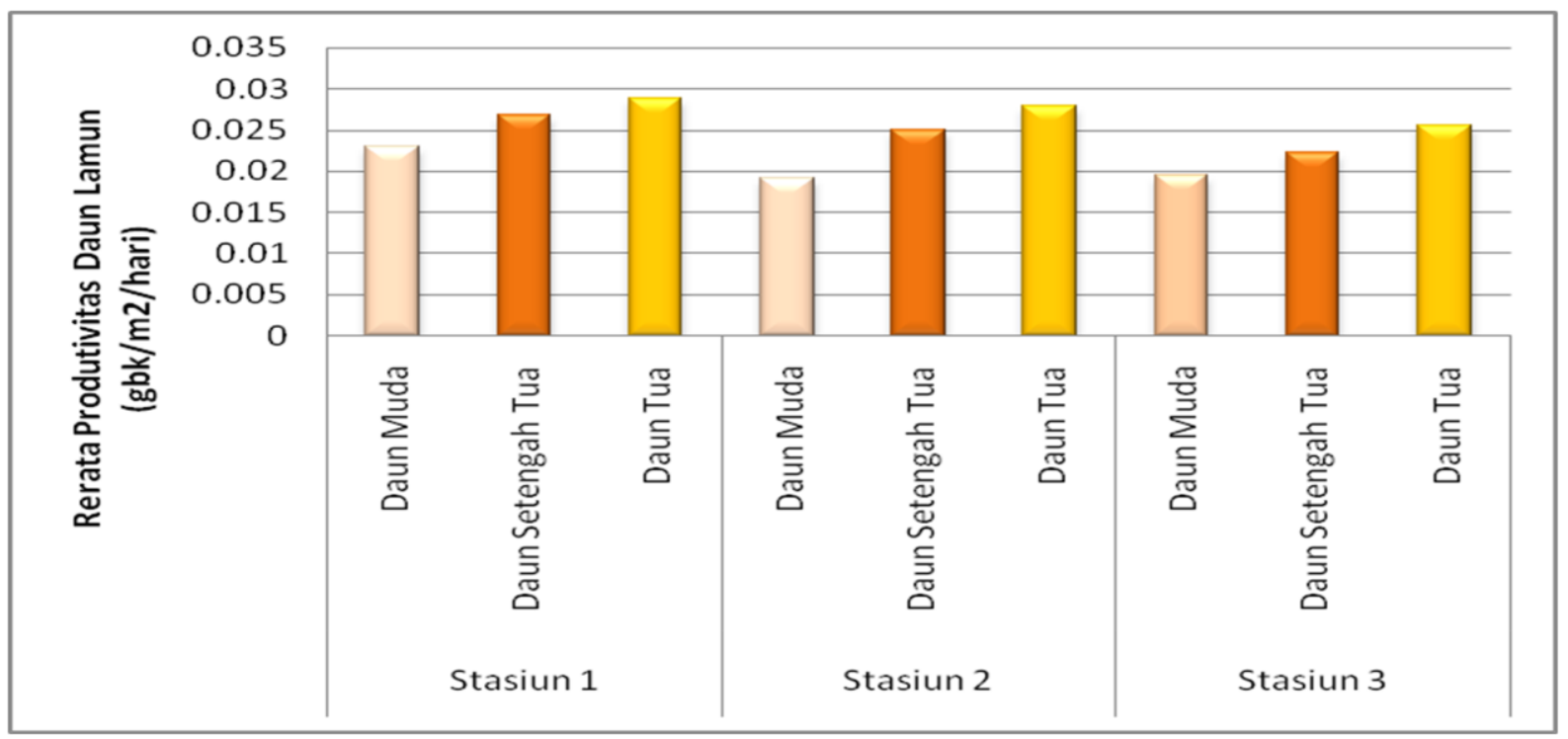

Gambar 5. Rerata produktivitas daun lamun Thalassia hemprichii

$0.023 \mathrm{gbk} / \mathrm{m}^{2} /$ hari, daun setengah tua sebesar 0.026 $\mathrm{gbk} / \mathrm{m}^{2} /$ hari, daun tua sebesar $0.028 \mathrm{gbk} / \mathrm{m}^{2} /$ hari pada stasiun kedua didapatkan nilai produktivitas daun muda sebesar $0.019 \mathrm{gbk} / \mathrm{m}^{2} /$ hari, daun setengah tua sebesar $0.024 \mathrm{gbk} / \mathrm{m}^{2} /$ hari, daun tua sebesar $0.027 \mathrm{gbk} / \mathrm{m}^{2} /$ hari. pada stasiun ketiga nilai produktivitas daun muda sebesar 0.019 $\mathrm{gbk} / \mathrm{m}^{2} /$ hari, daun setengah tua sebesar 0.022 $\mathrm{gbk} / \mathrm{m}^{2} /$ hari dan daun tua sebesar 0.025 $\mathrm{gbk} / \mathrm{m}^{2} /$ hari.

Selain kecepatan tumbuhnya, tinggi rendahnya nilai produktivitas daun lamun Thalassia hemprichii ini juga dipengaruhi oleh morfologi daunnya (lebar dan tebal) semakin luaus permukaan dan ketebalan daun maka berat produktivitas daun lamun juga akan semakain besar. Hasil pengamatan dilapangan didadapatkan bahwa di semua stasiun pengamatan dominan pasir yang diduga hasil dari produktivitas ini kecil dibandingkan dengan stasiun lumpur. Hal ini sejalan dengan yang disampaikan Feryatun (2012) bahwa pada stasiun lumpur ukuran daun lebih lebar dan tebal dibandingkan dengan stasiun pasir yang memiliki ukuran daun lebih kecil dan sempit.

Berdasarkan Gambar 4, hasil menunjukan bahwa daun tertua memiliki nilai tertinggi dan banyak menyimpan karbon disetiap stasiunnya ini diduga ada kaitannya antara biomassa daun dengan umur daun, juga dengan penyerapan karbon karena penambahan biomassa yang diperoleh dari hasil proses fotosintesis. Salah satu fungsi ekologis dari lamun adalah menfiksasi karbon. Rustam et al. (2014) mengatakan bahwa dalam melakukan fotosintesis lamun memanfaatkan karbon inorganik di kolom air sehingga lamun dapat mereduksi $\mathrm{CO}_{2}$ berdasarkan fungsi ekosistem lamun ini terlihat dengan jelas bahwa ekosistem lamun berperan sangat penting dalam siklus karbon di perairan laut terutama pesisir. Hal ini menunjukkan adanya kemampuan ekosistem lamun menenggelamkan (sink) $\mathrm{CO}_{2}$ dari atmosfer ke laut (dengan mekanisme adanya perbedaan tekanan parsial dari atmosfer ke laut) untuk fotosintesis yang kemudian tersimpan baik dalam bentuk biomassa lamun itu sendiri maupun tersimpan di dasar perairan atau sedimen.

\section{Simpulan}

Berdasarkan hasil penelitian yang telah di laksanakan adapun kesimpulan yang didapat dalam penelitian ini, pertumbuhan daun lamun Thalassia hemprichii antara kelompok umur daun hasilnya berbeda. Daun muda lebih cepat pertumbuhannya dibandingkan dengan daun setengah tua dan daun tua, ini menunjukan bahwa efisiensi pertumbuhan lamun ini akan semakin menurun dengan bertambahnya umur daun dan diduga kandungan unsur hara serta hormon dalam daun mempengaruhi pertumbuhan panjang daun.

Nilai biomassa tertinggi terdapat pada daun tua dibandingkan dengan daun muda dan daun setengah tua diduga karena ukuran daun yang tebal dan lebar yang mengakibatkan biomassa daun tua tersebut lebih besar. 
Nilai Produktivitas tertinggi terdapat pada daun tua sama halnya dengan daun tua memiliki nilai lebih besar dibandingkan dengan daun muda dan daun setengah tua yang diduga karena morfologi seta kandungan unsur hara yang berbeda disetiap jaringan daun.

\section{Daftar Pustaka}

Alie, K. (2012). Pertumbuhan dan Biomassa Lamun Thalassia hemprichii di Perairan Pulau Bone Batang, Kepulauan Spermonde, Sulawesi Selatan. Jurnal MIPA FMIPA Universitas Lampung, 16(2), 105-110.

Asriyana, A., \& Yuliana, Y., (2012). Produktivitas Perairan. Jakarta, Indonesia: Bumi Aksara.

Azkab, M. H. (2006). Ada apa dengan lamun. Oseana, 31(3), 45-55.

Christon, C., Djunaedi, O. S., \& Purba, N. P. (2012). Pengaruh tinggi pasang surut terhadap pertumbuhan dan biomassa daun lamun Enhalus acoroides Di Pulau Pari Kepulauan Seribu Jakarta. Jurnal Perikanan Kelautan, 3(3), 287-294.

Duarte, C. M., Marbà, N., Gacia, E., Fourqurean, J. W., Beggins, J., Barrón, C., \& Apostolaki, E. T. (2010). Seagrass community metabolism: Assessing the carbon sink capacity of seagrass meadows. Global Biogeochemical Cycles, 24(4), GB4032.

Faiqoh, E., (2015). Distribusi Spasial Dan Identifikasi Biodiversitas Lamun Di Perairan Tanjung Benoa. Dalam Prosiding Seminar Nasional Sains dan Teknologi (Senastek). Denpasar, Bali, Indonesia, 29-30 Oktober 2015 (pp. 3 -11).

Febriyantoro, F., Riniatsih, I., \& Endrawati, H. (2013). Rekayasa Teknologi Transplantasi Lamun (Enhalus acoroides) Di Kawasan Padang Lamun Perairan Prawean Bandengan Jepara. Jurnal Penelitian Kelautan, 1(1), 1-10.

Feryatun, F. (2012). Kerapatan dan Distribusi Lamun (Seagrass) Berdasarkan Zona Kegiatan yang Berbeda di Perairan Pulau Pramuka, Kepulauan Seribu. Management of Aquatic Resources Journal, 1(1), 44-50.

Hamid, A. (1996). Peranan faktor lingkungan perairan terhadap pertumbuhan Enhalus acoroides (L.f) Royle Teluk Grenyang-Bojongara Kabupaten Serang, Jawa Barat. Tesis. Bogor, Indonesia: Program Pascasarjana Institut Pertanian Bogor (IPB).

Graha, Y. I., Arthana, I. W., \& Karang, I. W. G. A. (2016). Simpanan karbon padang lamun di kawasan Pantai Sanur, Kota Denpasar. Ecotrophic: Journal of Environmental Science, 10(1), 46-53.
Hill, V. J., Zimmerman, R. C., Bissett, W. P., Dierssen, H., \& Kohler, D. D. (2014). Evaluating light availability, seagrass biomass, and productivity using hyperspectral airborne remote sensing in Saint Joseph's Bay, Florida. Estuaries and coasts, 37(6), 14671489.

Kaswadji, R. F., Bengen, D. G., \& Hutomo, M. (2012). Produktivitas komunitas lamun di Pulau Barranglompo Makassar. Jurnal Akuatika, 3(2), 159-168.

Kawaroe, M. (2009). Perspektif Lamun sebagai Blue Carbon Sink di Laut. Dalam Prosiding Lokakarya Nasional I Pengelolaan Ekosistem Lamun. Jakarta, Indonesia, 18 November 2009.

Kiswara, W. (2010). Studi Pendahuluan: Potensi padang lamun sebagai karbon rosot dan penyerapan karbon di Pulau Pari, Teluk Jakarta. Jurnal Oseanologi dan Limnologi di Indonesia. 36 (3), 361-376

Rahman, A. A., Nur, A. I., \& Ramli, M. (2016). Studi laju pertumbuhan lamun (Enhalus acoroides) di perairan pantai Desa Tanjung Tiram Kabupaten Konawe Selatan. Jurnal Sapa Laut (Jurnal Ilmu Kelautan), 1(1), 10-16.

Rahmawati, S. (2011). Ancaman terhadap komunitas padang lamun. Oseana, 36(2), 49-58.

Riniatsih, I., \& Endrawati, H. (2013). Pertumbuhan Lamun Hasil Transplantasi Jenis Cymodocea rotundata di Padang Lamun Teluk Awur Jepara. Buletin Oseanografi Marina, 2(1), 34-40.

Russell, B. D., Connell, S. D., Uthicke, S., Muehllehner, N., Fabricius, K. E., \& Hall-Spencer, J. M. (2013). Future seagrass beds: Can increased productivity lead to increased carbon storage?. Marine Pollution Bulletin, 73(2), 463-469.

Rustam, A., Bengen, D. G., Arifin, Z., \& Gaol, J. L. (2015). Dinamika Dissolved Inorganic Carbon (DIC) di ekosistem lamun Pulau Pari. Jurnal Segara, 10(1), 3141.

Simon, I. P., \& Rifai, H. (2013). Struktur komunitas padang lamun di perairan Pulau Mantehage, Sulawesi Utara. Jurnal Ilmiah Platax. 1(4), 177-186.

Takaendengan, K., \& Azkab, M. H. (2010). Struktur komunitas lamun di Pulau Talise, Sulawesi Utara. Oseanologi dan Limnologi di Indonesia, 36(1), 85-95.

Tasabaramo, I. A., Kawaroe, M., \& Rappe, R. A. (2015). Laju pertumbuhan, penutupan, dan tingkat kelangsungan hidup Enhalus acoroides yang ditransplantasi secara monospesies dan multispesies. Jurnal Ilmu dan Teknologi Kelautan Tropis, 7(2), 757-770.

(C) 2017 by the authors; licensee Udayana University, Indonesia. This article is an open access article distributed under the terms and conditions of the Creative Commons Attribution license (http://creativecommons.org/licenses/by/3.0/). 